\title{
STRATEGIC VEHICLES IMPORT SUPPLY CHAIN: A PARADIGM SHIFT IN AUSTRALIAN AUTOMOTIVE INDUSTRY
}

\author{
Kristina Malihi and Himanshu Shee* \\ Supply Chain and Logistics Discipline, Victoria University, Melbourne, Australia \\ *Corresponding author: Himanshu.Shee@vu.edu.au
}

Published online: 30 June 2017

To cite this article: Malihi, K. and Shee, H. (2017). Strategic vehicles import supply chain: A paradigm shift in Australian automotive industry. Asian Academy of Management Journal, 22(1), 103-130. https://doi.org/10.21315/aamj2017.22.1.5

To link to this article: https://doi.org/10.21315/aamj2017.22.1.5

\begin{abstract}
This study aims to formulate a buffer stock-adjusted make-to-stock (MTS) parts forecasting heuristic, which has the potential to ease the tight dispatch lead time issue facing first tier suppliers in vehicles import supply chain. The research is motivated by an issue of justin-time (JIT) parts dispatch to auto companies partly due to inadequate lead time given to the first tier suppliers. Compiling secondary data from industry sources, we estimated the overseas shipment time and parts dispatch lead time while developing heuristics to forecast vehicles parts requirement with due care for buffer stock. Results suggest a strategic hybrid approach combining MTS parts ordering with JIT supply to auto manufacturers. MTS will help first tier suppliers to source and stock parts in-house that can be supplied just in time to help completing vehicle fitment. This approach is likely to ease the lead time pressure of first tier suppliers without affecting JIT supply to the automotive companies. The study concludes with theoretical and practical implications for Australian first tier parts importers as well as automotive companies.
\end{abstract}

Keywords: parts forecast heuristics, make-to-stock inventory, vehicles import supply chain, lead time, automotive industry, Australia

(C) Asian Academy of Management and Penerbit Universiti Sains Malaysia, 2017. This work is licensed under the terms of the Creative Commons Attribution (CC BY) (http://creativecommons. org/licenses/by/4.0/). 


\section{INTRODUCTION}

The automotive manufacturing in Australia has recently gone through a major paradigm shift in relation to vehicle manufacturing. With the decision of manufacturing to discontinue within Australia after December 2017 (TheAustralian, 2014), the passenger car manufacturers soon will be moving away from targeted export-based manufacturing to a new paradigm. The ongoing announcement of plant closure and employee redundancies in both the automotive assembly and component making sectors shows that the highly subsidised automotive manufacturing is finally shifting from only car export to cars and component parts import supply chain. Despite government incentives and austerity measures to bail the auto manufacturers out from the financial crisis (Productivity Commission, 2016), sustaining operational efficiency (i.e., cost saving) was not achievable. The on-going deep-rooted structural problems prevented the industry from being competitive with other importing auto makers in the region (Wright, 2006). When the manufacturers like Ford, GM-Holden, and Toyota are respectively moving in to a complete closure of manufacturing, their focus is obviously turning to vehicles trading through import. With the share of small car import being 92 per cent back in 1999 and until recently (FCAI, 2015; Tcha \& Kuriyama, 2003), the car manufacturers have already been focusing on medium-size sedan cars assembly (e.g., Toyota Camry and Aurion) that also stands unsustainable lately.

With this backdrop, Australian automotive industry needs an investigation to succinctly articulating the contemporary issues the industry facing now. With this paradigm shift in manufacturing, vehicle import and parts fitment remain all time challenge in a tightly controlled just-in-time (JIT) delivery mechanism. JIT sourcing of vehicles and component parts has therefore become the major discussion in this strategic import supply chain. The import supply chain is not different from supply chain in general but we define it as the integrative way of sourcing component parts from second tier overseas suppliers and delivering to the auto companies in just in time manner. Literature review shows a very limited research on Australian automotive supply chain specifically in relation to vehicles import that has dominated the business recently. Studies on Toyota culture and social dimension (Jayamaha, Wagner, Grigg, Campbell-Allen, \& Harvie, 2014; Wright, 2006), automobile supply chain issues and risks (Singh, Smith, \& Sohal, 2005), global integration of production and distribution (Fahimnia, Farahani, \& Sarkis, 2013), and supplier integration research (Bennett \& Klug, 2012) dominant the literature. Manufacturing was advocated long time for its orientation towards Asia-Pacific supply chain rather than inwardly looking domestic market competitiveness. The trade policies such as import tariff cut, quotas, and content requirements followed by tax benefits for $\mathrm{R} \& \mathrm{D}$ activities etc. could not somehow 
support the industry to survive (Productivity Commission, 2016). This is due partly to the high cost of manufacturing operations fueled by consistent higher domestic demand for overseas-assembled small cars (Singh et al., 2005; The Australian, 2014). We notice the extant research highlights the auto manufacturing and supply issues in UK, USA, Japan, and European context; no research however occurs on import chain specifically vehicle dispatch lead time issue in Australian context. We refer the 'dispatch lead time' as the limited time (in days) available to first tier component suppliers who receive parts from overseas second tier suppliers and deliver them to fitment centre. This study focuses on the issue of lead time that is too inadequate resulting in high level of stress among the import chain partners in general, and first tier part suppliers in specific. No earlier studies have addressed this issue yet.

As Australian automotive industry is highly reliant on overseas parts suppliers, Liker and $\mathrm{Wu}$ (2000) suggest suppliers' close geographical proximity as an alternative and reasonable solution to manage the lead time issue. Fahimnia et al. (2013) argue for significant cost saving by way of global integration of production and distribution decision in a complex supply chain (Gunasekaran, Subramanian, \& Rahman, 2015). Singh et al. (2005), however, state that establishment of 'supplier park and in-line sequencing' for lead time reduction has had mixed success earlier. Some suppliers have used this opportunity for their own manufacturing while others have set up just a warehousing, and the remainders view this as an avenue of additional cost. This approach was risky overall and remained unsuccessful (Fiksel, Polyviou, Croxton, \& Pettit, 2015).

While implementation of lean and JIT practices have profound impact in the relationship between automotive assemblers and first tier parts supplier through benefit of cost reduction and increased efficiency (Morris, Donnelly, \& Donnelly, 2004; Prajogo, Oke, \& Olhager, 2016), integrated parts ordering cycle and associated lead time issue in this process remains a matter of investigation. We refer JIT supply as an instantaneous order fulfillment of spare parts or sub-assemblies from the available stock at the level of first tier part supplier in response to the orders received from the auto assembler. The common practice is that Australia's first tier suppliers coordinate with second tier overseas suppliers for spare parts sourcing for achieving competitive advantage (Lii \& Kuo, 2016). The first tier supplier then hands in the spare parts or sub-assemblies to the fitment centres of auto manufacturers. Under this arrangement, first tier suppliers, as mediator, come under constant challenge and threat of accomplishing the task within a given but inadequate lead time. It therefore raises a question whether dispatch lead time simplification could anyway help the first tier part suppliers delivered the component parts just in time to auto manufacturers. 
In this study, therefore we aim to assess the dispatch lead time issue at the level of first tier suppliers thereby arguing whether make-to-stock (MTS) environment can be coupled up with JIT supply in order to achieve a feasible solution. The rest of the paper is organised as follows. The next section will cover literature review with discussion on industry at a glance, general concept of JIT manufacturing, make-to-order (MTO), and MTS ordering environment in context of automotive supply chain. This follows next section on qualitative methodology employed. The detailed overview of auto import logistics integrated process is elaborated in next section to show parts ordering process, vehicle dispatch lead time issues, and order quantity determination currently practiced in industry. The paper concludes with discussion and implications for auto assemblers and first tier parts suppliers.

\section{LITERATURE REVIEW}

\section{Industry at a Glance}

In an announcement early 2014, three major Australian automotive manufacturing companies (e.g., Ford, Holden, and Toyota) declared respectively the closure of their production plants by the end of 2017 (The Australian, 2014; Productivity Commission, 2014). The reasons mentioned are due partly to stronger Australian dollar, stronger global competition, high cost of manufacturing, and lower economies of scale that together making the car manufacturing unviable. For example, only $40 \%$ of total domestic vehicle production was exported in 2012 and about $92 \%$ of new vehicle sales (over one million per year) in Australia are imported (Productivity Commission, 2014). This shows that Australian customers have been buying increasingly more cars imported from overseas facilities at Thailand, Japan, Korea, Germany, and USA. This is further fuelled by the Australian government recent announcement to cut the import tariff down in Australia-Japan free-trade agreement effective from 15 January 2015. The forecast is that the import will continue to increase within the following years as a result of closure of the local manufacturing. Despite auto industry's value-added contribution remained at 5.3\%, Australian Federal Government assistance will cease to offer after December 2017. Even the import tariff currently at 5\%, the industry experienced changing consumer preference for fuel efficient and cost effective imported small cars. Thus, the vehicles and its import supply chain is going to play a critical role which warrants a special investigation on lead time issues that has not been documented yet. 


\section{JIT Manufacturing}

JIT approach to automotive manufacturing comes at the cost of tightly coordinated processes in a supply chain (Jacobs, Berry, Whybark, \& Vollmann, 2011). Automotive import supply chain thus comprises of auto producers who undertake final customisation of the import vehicles and component suppliers who help in the JIT supply of component parts. Traditionally auto producers happen to outsource supply of component parts to component manufacturers/suppliers within the supply chain often termed as 'tiers', with first tier suppliers supplying directly to the producers/assemblers, second tier suppliers supplying the first tier suppliers, and so on. While customising a car for a customer in a MTO environment (Jacobs et al., 2011, p. 21), each auto company supply chain is traditionally engaged with timely procurement of component/spare parts from the first tier suppliers. The challenge behind components procurement is all about to appropriately balance and execute the inventory procurement and managing the timely flow of logistics along the chain (Svensson, 2003). It appears that first tier part suppliers are increasingly experiencing a tight time schedule thereby unable to cope up with JIT assembly at Australian auto companies. Given the Australia's geographical remote location further away from those second tier overseas suppliers, the first tier suppliers appear to have continuous issues to coordinate and manage an uninterrupted parts supply. While the auto manufacturers from Australia are well established in executing JIT practices, the first tier suppliers seem to have hard time to deal with when they operate close to their manufacturers or end customers. Given the future of the auto industry overly reliant on more vehicles import and subsequent parts fitment for final delivery, the first tier suppliers will be in dare need of a mechanism to improve managing the JIT supply to auto assemblers with current lead time issues around the parts supply. This paper addresses the unique issue that has not been considered earlier.

\section{MTO, MTS, and JIT in a Supply Chain}

MTO, MTS, and JIT are mostly concerned with production system that links to customer ordering environment (Jacobs et al., 2011; Rafiei \& Rabbani, 2012). JIT philosophy is based on zero-inventory concept (theoretically) and attempts to eliminate waste (referred as lean) within a system (Daugherty, Rogers, \& Spencer, 1994). Referring to many definitions and philosophies of JIT in literatures, the one used by Doran (2001) is preferred over others and states that "JIT facilitates costeffective production and delivery of the exact quantity of parts at the right quality, at the right time and place, while using a minimum amount of facilities, equipment, materials and human resources" (p. 116). It follows a disciplined and systematic 
way to MTO production environment that is well practiced in automotive sector (Doran, 2001). Introduced by Shigeo Shingo and then Taiichi Ohno at the Toyota Motor plant Japan in mid-1970s, the JIT production system has been a point of much attention since its implementation (Ōno, 1988) and predominantly influences all assembly production. The JIT production is founded on three fundamental principles: waste elimination, continuous quality improvement, and worker participation incentives (Harber, Samson, Sohal, \& Wirth, 1990). Automotive manufacturing, for example Toyota production system, strives to continuously shorten the cycle time (i.e., from the point of receiving customer order to the point of cash collection) by removing non-value added wastes (Jayaram, Das, \& Nicolae, 2010; Womack \& Jones, 1996). It is an intelligent approach to lean manufacturing that Toyota is known for decades (Li, 2013). Angelis, Conti, Cooper, Faragher, and Gill (2004) however focus on significant job stress caused by a range of lean practices and degree of lean implementation based on manufacturing survey in UK industry sectors.

One of the challenges of Toyota production system is to ensure timely delivery of defect free vehicles to the end customers. This demands a flexible production line with MTO approach that can produce in the shortest lead time possible. This study thus focuses on the lead time issues that first tier suppliers are concerned about while supplying the parts just in time to auto assembler. Toyota and other auto assemblers practice JIT principle (Liker, 2003; TMCA, 2004) where JIT strongly believes in manufacturing with zero or minimal in-process inventory, shortened lead time, and remarkable savings in carrying costs. Considering JIT practices within the auto assembly and its end-to-end vehicles import supply chain, we believe in further investigation of JIT supply along the chain and its associated work pressure arising from tight lead time. While focusing on Toyota production system, Jayaram et al. (2010) investigate the impact of lead time on assembly cycle time and delivery performance. However, the tight dispatch lead time with first tier suppliers has been an issue considering their location far away from second tier overseas suppliers. First tier suppliers have been experiencing hard time while coordinating JIT supply with auto assemblers. Getting the supply from second tier overseas suppliers (mostly in Asia region) with seven rights of logistics (e.g., right product, right customer, right quantity, right condition, right place, right time, and right cost) (Russell, 2000) remain an all-time challenge for the whole chain and first tier suppliers in specific (Bartezzaghi, Cagliano, Caniato, \& Ronchi, 2016).

JIT techniques can influence the most at the back-end of the assembly where it pursues various orders for customers, for example, MTO and MTS (Jacobs et al., 2011). Based on customer specific requirement, MTO focuses on average response time, delivery lead time, and due dates (Rafiei \& Rabbani, 2012; Soman, 
Van Donk, \& Gaalman, 2004). JIT technique is suitable for MTO environment for JIT procurement, sub-assembly, and final assembly, including JIT delivery to the customers. MTS however manages finished or semi-finished inventories produced ahead of customer order. MTS thus focuses on forecast-based production, warehousing before meeting the customer orders from the available stock (Rafiei \& Rabbani, 2012; Soman et al., 2004). Limiting to hybrid MTS/MTO approach in a production environment, Rafiei and Rabbanis' (2012) model focuses on lot-sizing MTS products and capacity determination. Explaining the modus operandi of hybrid MTS/MTO systems, Rafiei and Rabbani (2012) elaborate it as "a common section of the line dedicated to process MTS parts of different products and the remaining section of the line attempts to differentiate end items upon incoming orders". This study develops this hybrid concept further to source parts along an import chain where first tier supplier interacts with second tier overseas suppliers. Doran (2001) differentiates JIT from synchronous supply. Synchronous supply is an integrated supply of goods to match the exact requirement of each assembly seating necessitated by close proximity to assemblers (Doran, 2001). We find vehicles import supply chain resembles a synchronous supply of spare parts by first tier suppliers along the import chain. Talking about the notion of 'close proximity' for an effective synchronous and JIT operations, Bennett and Klug (2012) posit that suppliers' close geographical proximity improves transport responsiveness from finished component to assembly centres and maximise reliability without delivery disruption even in condition of bad weather and traffic. However, Liker and Wu (2000) argue that geographical distances and supplier proximity is not an issue as Japanese transplants have found 'milk runs', or compound deliveries as a means to compensate the geographical distances and non-proximity of suppliers. Though first tier suppliers' location in Australia context is very close to the auto assemblers within the geographical boundary, it is yet to be considered disadvantageous as the first tier suppliers overly depend on second tier overseas suppliers where lead time management has been an issue. This is quite important point of discussion here in this study as the business is moving towards vehicles import as a measure of sustainable practice ( $\mathrm{Wu}$, Tseng, Chiu, \& Lim, 2016). No such study is evidenced yet in literature.

\section{METHODOLOGY}

\section{Sample and Data Collection}

This study used a sample of half a dozen of automotive companies in an exploratory study to collect published secondary data and analysed them to develop an understanding of 'real world' business practices (McCutcheon \& 
Meredith, 1993; Robson \& McCartan, 2016). The combination of qualitative data with little quantitative secondary data used in this study is referred as 'real world flexible design' methodology as proposed by Robson and McCartan (2016). We started exploring secondary data on vehicle import business practices in Australia, followed by an investigation of the actual situation of JIT supply of spare parts to companies' fitment centre. Companies like Toyota, Ford, Holden, Hyundai, and others import spare parts regularly from domestic first tier component suppliers who in turn get the parts from overseas second tier suppliers. As JIT assembly is quite prevalent in automotive sector, these selected auto companies together represent a good sample for this study. Further, they jointly represent about $60 \%$ market share (in import volume percent) in Australia automotive sector. Therefore, the data collection process commenced with secondary data from the first tier suppliers/parts importers as well as the automotive companies.

Australia's automotive industry is a wide-ranging industry involving automotive manufacturing, component manufacturing and distribution, parts suppliers, and transporters. We focus on only two partners, namely the auto companies and first tier parts supplier/importer as they conveniently located in Australia. The second tier suppliers who come from overseas market appear as constituent import chain partner in this study but not a part of this study. Further, we have used secondary data on vehicles import from various sources including industry bodies, government statistics, productivity commission Australia (Productivity Commission, 2014) and industry reports through Federal Chamber of Auto Industry (FCAI, 2015) (Table 1). The data pertaining to shipment lead time from Japan to Australia, first tier suppliers' parts delivery lead time to fitment centres, and overseas second tier suppliers' part delivery lead time to first tier suppliers were obtained and compiled from auto companies, first tier suppliers, logistics providers, and shipping line schedule (Shipping Schedules, 2015; TNT, 2015). In addition, we used Customer Order Web tracking systems that update customer vehicle ordering status in the form of delivery lead time (Toyota, 2016). A summary of vehicles import in Australia showing number of imported vehicles under each category, core activities undertaken by each assembler, imported countries, and shipment lead time is presented in Table 1. Japan-Australia vehicle import lead time is used as an example in this study.

\section{Data Analysis Techniques}

Secondary published data on vehicles import are presented in a tabular form (Table 1) to show various model types and the countries the vehicles are sourced to Australia. Table 1 further summarises volumes of imported vehicles, percentage of import, core process types, and employees of the companies involved in the 


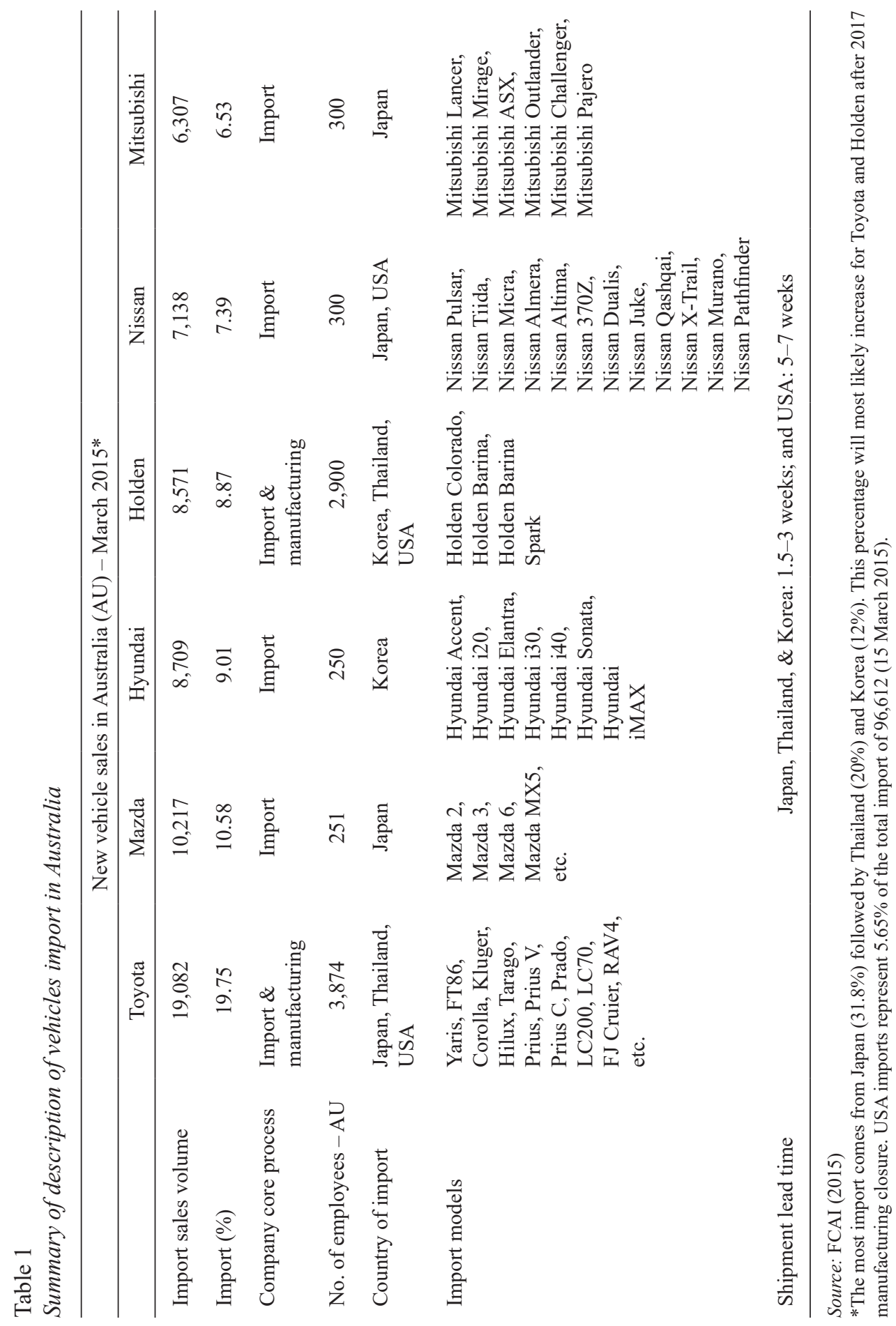


car import. The shipment lead time (days) from Japan to Australia (Figure 4) and lead time (days) for first tier supplier to receive the parts from overseas suppliers (Table 2) (TNT, 2015) are superimposed in Figure 5 to show a clear situation of tight JIT operation within the given lead time. The lead time data in Table 2 is estimated from the average days the shipment takes from Japan to deliver vehicles at different cities in Australia. Other flow diagrams indicating import lead time and parts ordering cycle (see Figures 6, 7, and 8) are self-drawn by authors to better depict the steps involved in the importation process. Finally, a heuristic is formulated for the first tier supplier's order quantity to the overseas suppliers. While the first tier supplier receives a forecast stock order requirement for $\mathrm{N}+3$ months from the auto companies, the proposed heuristic is modeled to hold some buffer with due consideration to any excess or shortage of component parts from previous period. This approach avoids any carrying cost of holding inventory.

\section{Overview of the Australian Auto Companies Vehicle Import Supply Chain Process}

The vehicle logistics import supply chain in general consists of eight steps: (1) vehicle ordering, (2) parts forecasting, (3) vehicle production and shipment, (4) parts ordering, (5) parts delivery, (6) vessel arrival, (7) parts fitment, and (8) final dispatch of vehicles to the dealership (customer). Schematic representation of Australian vehicle import logistics supply chain is presented in Figure 1. The following sections elaborate on each step.

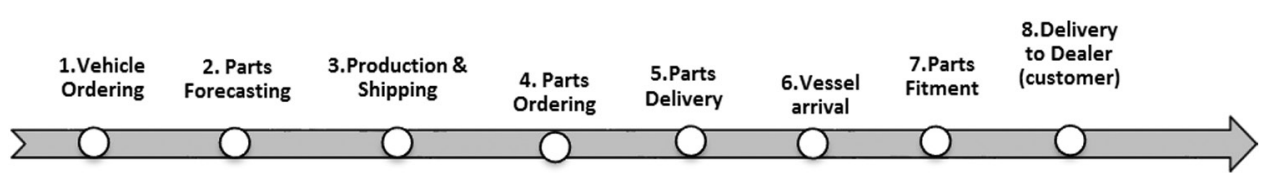

Figure 1. Vehicle import logistics supply chain

\section{Vehicle ordering}

The import supply chain process commences with vehicles order to overseas manufacturing facilities, one month $(\mathrm{N})$ prior to vehicle production based on the current month of the customers' orders. Overseas vehicle manufacturer then determines the final number of vehicles which will be shipped to Australia for the next month (Figure 2). 


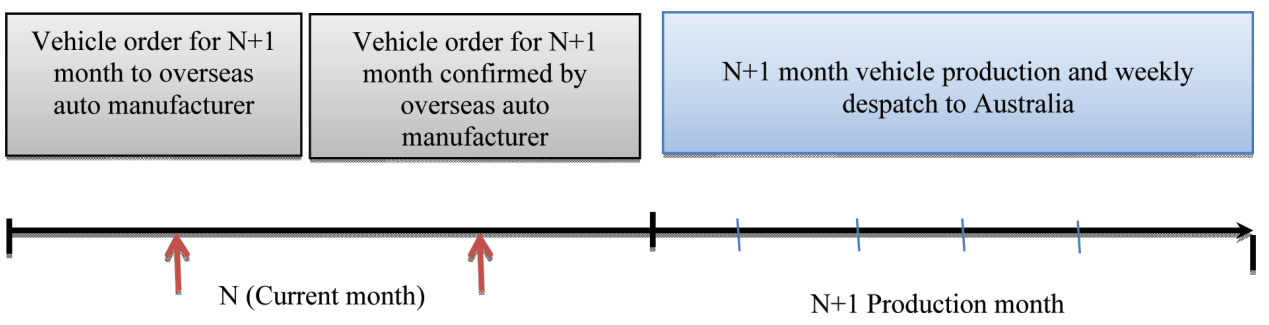

Figure 2. Import lead time - vehicle order cycle

\section{Parts forecasting}

Corresponding to overseas manufacturer's confirmed vehicles delivery information, the Australian automotive company's logistics department develops parts forecasting information for its parts suppliers. This usually occurs by the end of each month. This process ensures timely availability of the weekly actual parts quantity for $\mathrm{N}+1$ production month.

This forecast information also helps the first tier parts suppliers to develop their parts forecasting process, manage their stock level, and place orders to their overseas second tier suppliers who serve with long lead times. The Australian auto company's parts forecast provides a $\mathrm{N}+1$ month confirmed parts requirement according to the confirmed vehicles orders from overseas auto manufacturer. Some of the companies provide first tier suppliers at least two months (i.e., $\mathrm{N}+2 \& \mathrm{~N}+3$ ) indicative requirements calculated from historical sales and other variables that may impact the future parts/vehicle volume requirements. Alternatively, the first tier suppliers develop its own forecast process based on the same historical take up logic and other variables that may be impacting the forecast at the certain time such as seasonal demand, end of the year sales, special offer sales, and so on. The suppliers, however, are required to readjust their stock levels for $\mathrm{N}+2$ and $\mathrm{N}+3$ months once the confirmed volume is received for $\mathrm{N}+1$ month from the Australian auto companies. The monthly parts forecasting process flow based on vehicle ordering aand forecasting is depicted in Figure 3.

\section{Vehicle production and shipping}

Australian imported vehicles are produced in more than 26 countries (FCAI, 2015). This study has taken into consideration the lead time from Japan as an example. Japan auto import stands at the highest contribution $(31.8 \%)$ of the total Australian vehicle import followed by Thailand (20\%) and Korea (12\%) vehicle import (FCAI, 2015). In most cases, vehicles are shipped on a weekly 


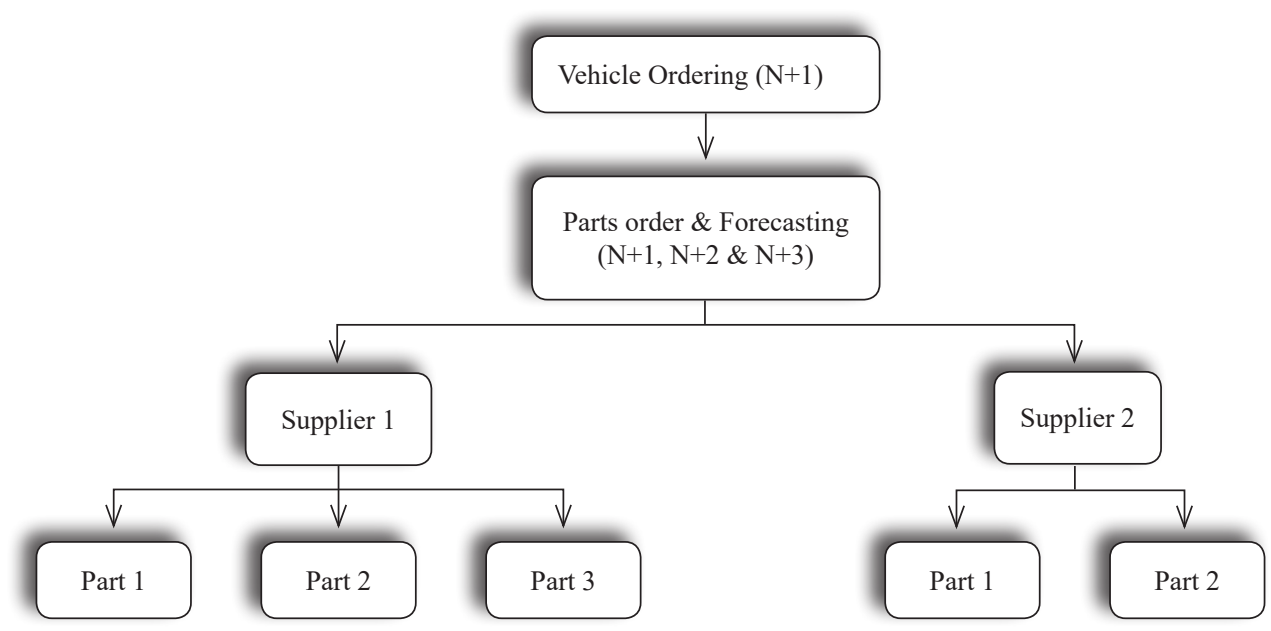

Figure 3. Parts forecast flow

basis to the Eastern Australian ports (e.g., NQ, SQ, NSW, VIC, SA), and once or twice a month to Western Australia (WA) and Northern Territory (NT). On average, Australia imports over 90,000 vehicles per month across all new models with the highest import being in passenger segment with around $46 \%$ of the total market segmentation. The shipping routes and respective lead time for importing vehicles from Japan are indicated in Figure 4 (Shipping Schedules, 2015). For example, shipment from Japan to Townsville thus takes about 10 days, 16 days to Melbourne, and 13 days to Fremantle. Toyota is currently the highest volume auto import leader followed by Mazda, Hyundai, and Holden (FCAI, 2015).

\section{Shipping from Japan}

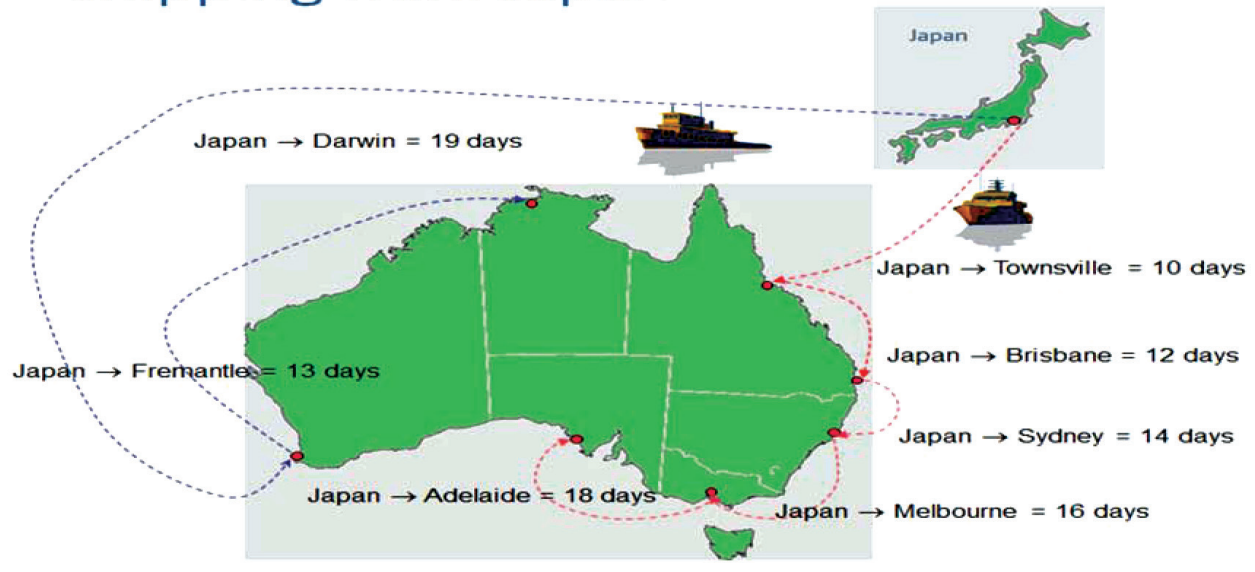

Figure 4. Shipment frequency and lead times for Japan arrivals at Australia 


\section{Parts ordering}

Under normal circumstances, after two days of the vessel departure from Japan, the shipping information for the vehicles that have departed from certain overseas port are received by Australian auto company's IT business system. This IT process updates the vehicles info and then triggers the creation of purchase order (PO) numbers for port-fitted parts for each vehicle. The PO numbers are sent to each of the first tier parts suppliers.

Most of the first tier parts suppliers based in Australia are located within Victoria (VIC) and New South Wales (NSW). Only 10\% of parts suppliers have manufacturing in Australia, with the remaining 90\% acting as warehouse or distributors for their sub-suppliers' production facilities in Asia. The main distribution function is to pick, pack, and dispatch the ordered parts at this customer order decoupling point (CODP) between the manufacturer and first tier suppliers. CODP refers to the most important stock point in the material flow where product flow is linked to the specific customer order (Hoekstra \& Romme, 1992; Jodibauer, Olhager, \& Schonberger, 2012). The first tier part suppliers also have to ensure they have the required volume of parts when auto company's PO is received. Under the circumstances, the parts must be met from the current stock or must arrive just in time from overseas.

\section{Parts delivery and dispatch lead time}

All parts are required to be delivered at importing company's vehicle fitment site prior to vessel arrival to ensure port parts fitment and timely vehicle delivery to the end customers; a philosophy that aligns with JIT supply. Approximate delivery or dispatch lead time (in days) which is almost fixed for first tier suppliers are presented in Table 2. VIC and NSW suppliers are fixed at two days where, North Queensland (NQ) and NT are at five days. Delivery date stated in the PO must be achieved at all times.

\section{Vessel arrival and parts fitment activity}

Once the vehicle shipment arrives in Australian ports, vehicles are unloaded and parked in assigned arrival port laydown area by the local wharf appointed personnel. The imported vehicles are finalised for the final customer despatch once they undergo the process of port parts fitment in order to meet customer requirements and Australian regulation compliance. Some examples of the parts fitment include audios, decals, labels, sports bars, compliance labels, and warranty and service books. 
Table 2

First tier parts supplier lead time for processing site

\begin{tabular}{cc}
\hline Processing site & Lead time (days) - fixed \\
\hline VIC & 2 \\
NSW & 2 \\
SA & 3 \\
SQ & 4 \\
NQ & 5 \\
NT & 5 \\
WA & 5 \\
\hline
\end{tabular}

Source: TNT (2015)

\section{Transport and delivery}

The finished vehicles are then booked for transport and despatched to the final customers by the appointed logistics transporters.

\section{Parts Order Placement and Issues}

\section{Parts fulfilment process}

JIT philosophy requires parts supply model to focus on elimination of excess and obsolete stock thereby achieving a smooth and efficient supply chain. The expectation of each auto company is that its parts suppliers commit delivery in full and on time (DIFOT). This may provide a challenge for the parts suppliers to comply with the automotive company's JIT environment. The current vehicles shipment from Japan and parts supplier despatch lead time is presented in Figure 5.

As per current practice, Australian auto company sends off parts forecast to their local first tier suppliers who pass on the information to their overseas second tier suppliers. Actual parts order (vs. forecasted) however is confirmed once the vessel departs port at Japan and the first tier suppliers are expected to process and issue the parts order to the overseas parts supplier two days after vessel departure.

\section{Parts fulfilment challenge for parts supplier}

By way of an example, let us consider vehicle shipment lead time from Japan to Townsville (NQ), which is 10 days. The total shipment time is comprised of few lead times set by importation process between vessel departure and arrival. The 


\section{Shipping from Japan}

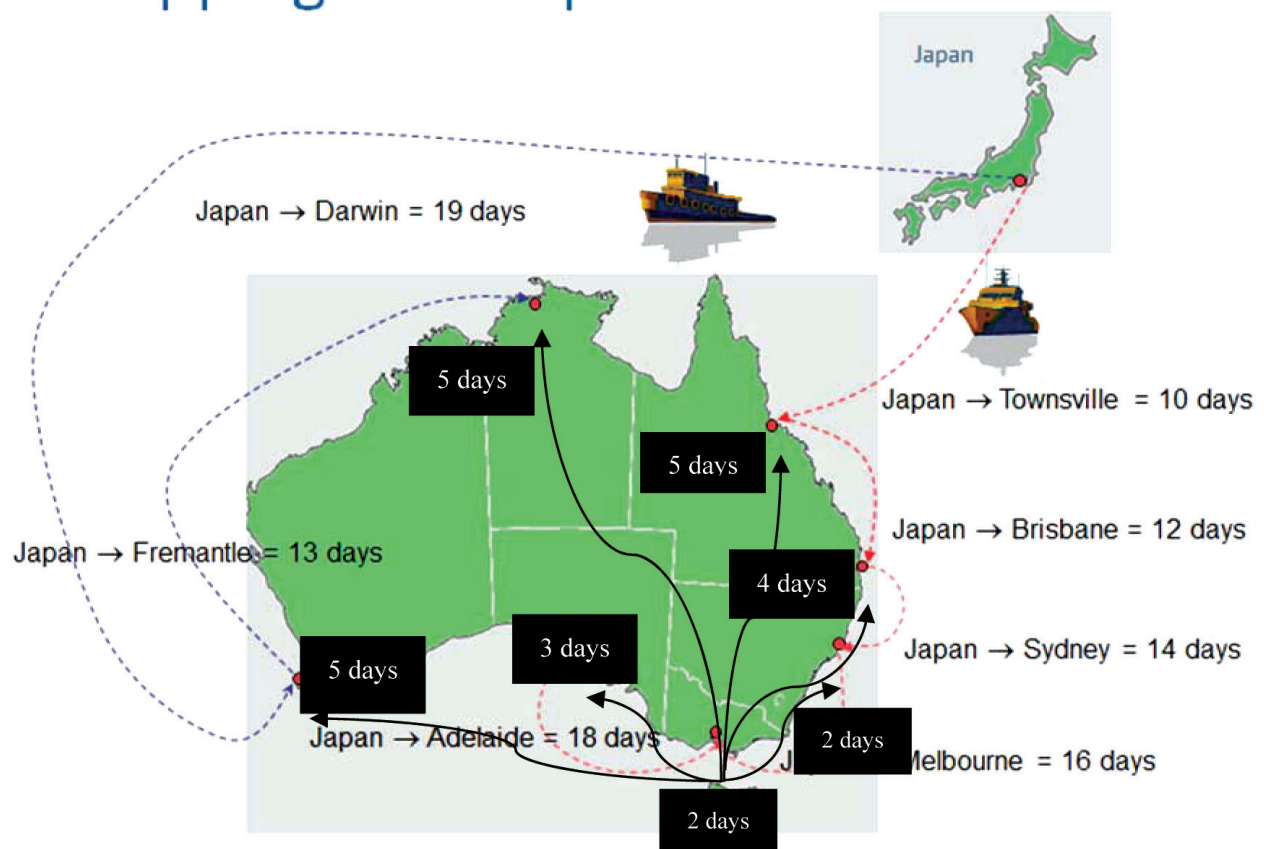

Figure 5. Vehicles arrival and parts dispatch lead time

shipment information received by the Australian auto company is fixed at two days after vessel departure from Japan. The lead time for the first tier supplier to transfer the parts to processing/fitment centre is fixed at five days (see Table 2); and the parts to be delivered at the processing centre is fixed at one day prior to vessel arrival (Figure 6). This results in the remaining lead time of just two days available for first tier supplier to processing the orders, packing, and delivers the parts to the fitment centres, which is the real issue to be investigated in this study.

By way of comparison, the processing sites such as Melbourne (VIC) and Darwin (NT) have their shipment time longer at 16 days and 19 days respectively. The maximum parts processing lead time for the first tier parts suppliers for these sites is 11 days. This however appears to be inadequate in certain situation as discussed below. The lead time calculation is based on the market condition when everything works as planned. However, there are periods when the companies are faced with issues beyond control. For example, the shipping data may be sent on the weekend due to the locked contract with the shipping lines for the weekly timing of vessel departure from Japan. When the vessel, for example, leaves on Thursday and the Australian importers receive the files on Friday afternoon, the shipping data will 


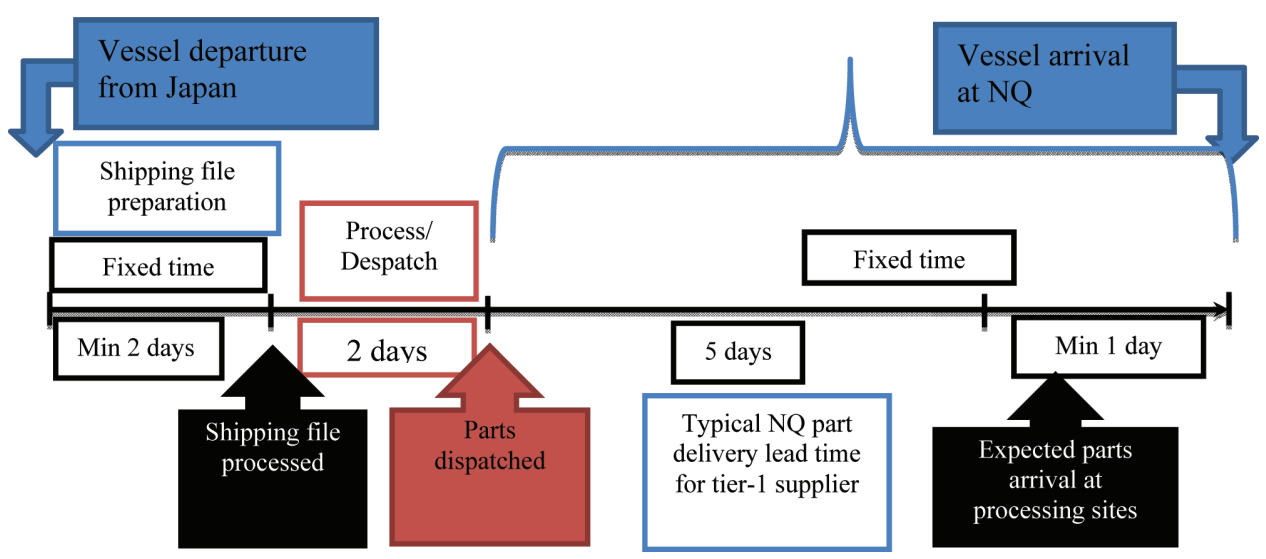

Figure 6. NQ import lead time - order cycle

be processed only on the following Monday, thereby first tier suppliers cannot send anything to second tier suppliers before Wednesday. Thus, total of five days are lost ever since the vessel departed from Japan. Consequently, two extra days allowance is very likely to cover up risk associated with any contingency and unplanned circumstances.

Given the above circumstances, it can be challenging for the first tier parts suppliers to supply parts just in time with only 2 to 11 days (or 0 to 9 days) to process the orders. This lead time therefore is also inadequate for the first tier suppliers to accomplish all such activities like processing, packaging, and dispatch. Another challenge is that the first tier suppliers are also reliant on their second tier parts suppliers overseas (mainly in Asia) who require a minimum lead time of 10 weeks (Figure 7), which is comprised of production of six weeks and shipment of four weeks.

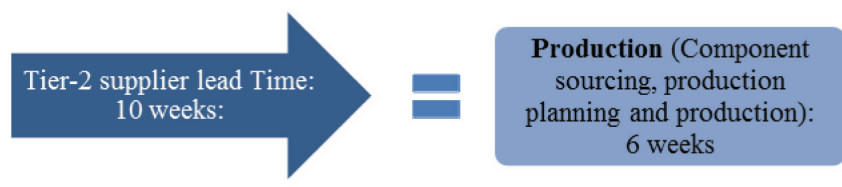

Import (Shipment) time: 4 weeks

Figure 7. Overseas second tier parts supplier lead time

Accordingly, the first tier supplier and Australian auto companies need to develop a mutual agreement on lead time in order to be able to receive the required parts on time from the appointed second tier supplier. The flow chart of parts forecast for $\mathrm{N}+1$ production month at auto companies is passed on to the first tier suppliers and second tier suppliers is illustrated in Figure 8. 


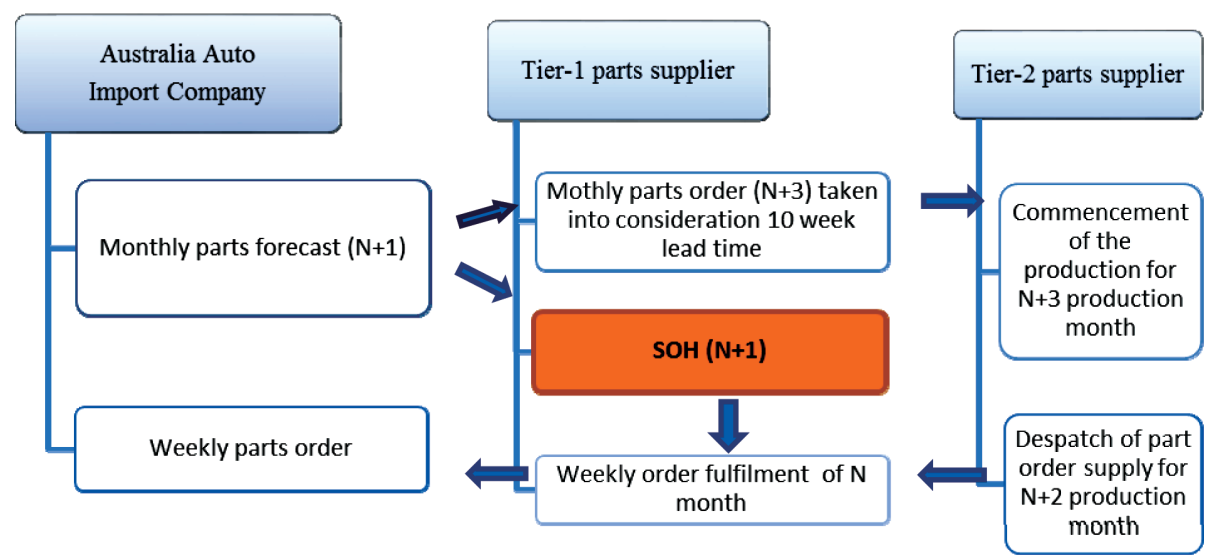

Figure 8. Parts supplier (tiers $1 \& 2$ ) order cycle in (N) current month

In reality, getting into the business of JIT supply is always challenging. The first tier suppliers find the JIT process somehow difficult to achieve, pushing them to supply through MTS arrangement with their second tier overseas suppliers. MTS, however, can introduce the risk of inventory obsolescence and carrying cost under changing market demand. Reasons for MTS method of ordering are manifold. The auto company sends the confirmed volume forecast for $\mathrm{N}+1$ production month. However, the first tier supplier places order for three months in advance $(\mathrm{N}+3$ month) to its second tier supplier given that the second tier supplier demands longer lead time at 10 weeks. The process flow is explained in Figure 9.

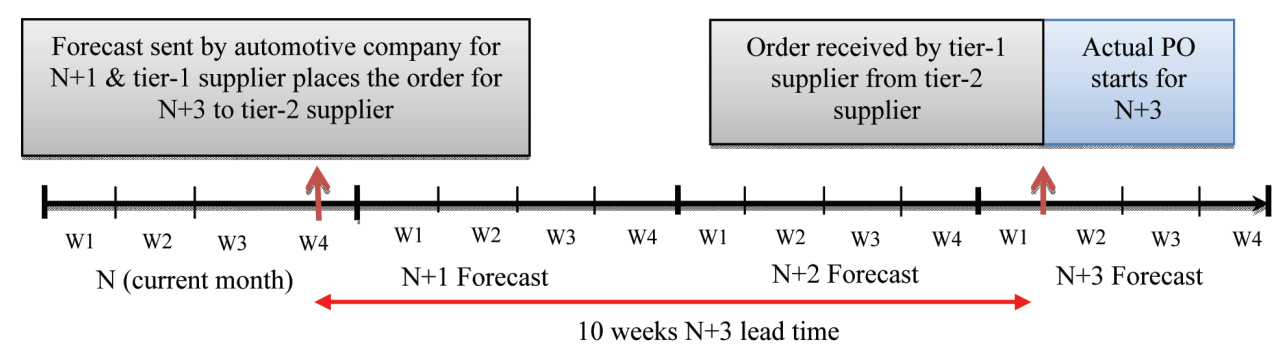

Figure 9. Import lead time - parts order cycle

As a result, this forecasting approach requires the suppliers to constantly adjust their stock-on-hand $(\mathrm{SOH})$ situation once they receive actual month orders from automotive companies (Table 3). The first tier suppliers thus need to place appropriate quantities to their second tier suppliers making sure that parts are available upon receipt of PO order. Question therefore is, how much will be the $\mathrm{N}+3$ month forecast for second tier supplier estimated at current month? This is illustrated through a heuristic in the section below. 


\section{Modeling the first tier supplier's order quantities}

Given the 10 weeks lead time requirement at second tier supplier, the first tier supplier needs an early order of $\mathrm{N}+3$ month of parts requirements in current month. Considering automotive company's indicative parts forecast for $\mathrm{N}+1$ month (from Figure 8), it may likely to have either excess or shortage of the current $\mathrm{SOH}$ at first tier supplier. The actual stock situation will depend on whether the forecast volume for $\mathrm{N}+3$ month [estimated in current $(\mathrm{N}+3) \mathrm{n}$ month] may be either higher or lower than the actual requirement for two months later. Therefore, the first tier supplier needs to perform an ongoing stock adjustment of its order quantities before a decision taken to place the next order.

For example, we assume hypothetically the forecast volume for $\mathrm{N}+3$ month (September), estimated three months ago (June), $(\mathrm{N}+3) \mathrm{n}-3$, as 188 units. That means the first tier supplier placed an order of 188 units to second tier supplier three months earlier due to lead time constraint of 10 weeks. However, due to changing market condition if current month (say August) firm forecast for $\mathrm{N}+1$ month (i.e., September) apparently changed to 180 units, the first tier supplier will need to adjust the stock difference for eight units. He will otherwise end up with eight units in excess in $\mathrm{SOH}$ (Table 3).

The first tier supplier therefore will need to adjust their current $\mathrm{N}+3$ month order in August of 230 units (for example) after deducting the excess eight units, i.e., 222 units for November. The optimum stock or net requirement (On) in the form of planned order for $\mathrm{N}+3$ month is calculated as below:

$$
\mathrm{On}=(\mathrm{N}+3) \mathrm{n}-[(\mathrm{N}+3) \mathrm{n}-3 \sim(\mathrm{N}+1) \mathrm{n}]
$$

where,

$\mathrm{On}=$ first tier supplier order for $\mathrm{N}+3$ months placed in $\mathrm{N}$ (current) month

$(\mathrm{N}+3) \mathrm{n}=$ indicative $\mathrm{N}+3$ forecast estimated in $\mathrm{N}$ (current) month

$(\mathrm{N}+3) \mathrm{n}-3=$ indicative $\mathrm{N}+3$ forecast revised three months $(\mathrm{n}-3)$ ago

$(\mathrm{N}+1) \mathrm{n}=$ company's actual requirements in $\mathrm{N}$ (current) month

On $=230-(188-180)=230-8=222$ units to be ordered by first tier to second tier supplier in $\mathrm{N}$ month (August) (estimated in Table 4). 


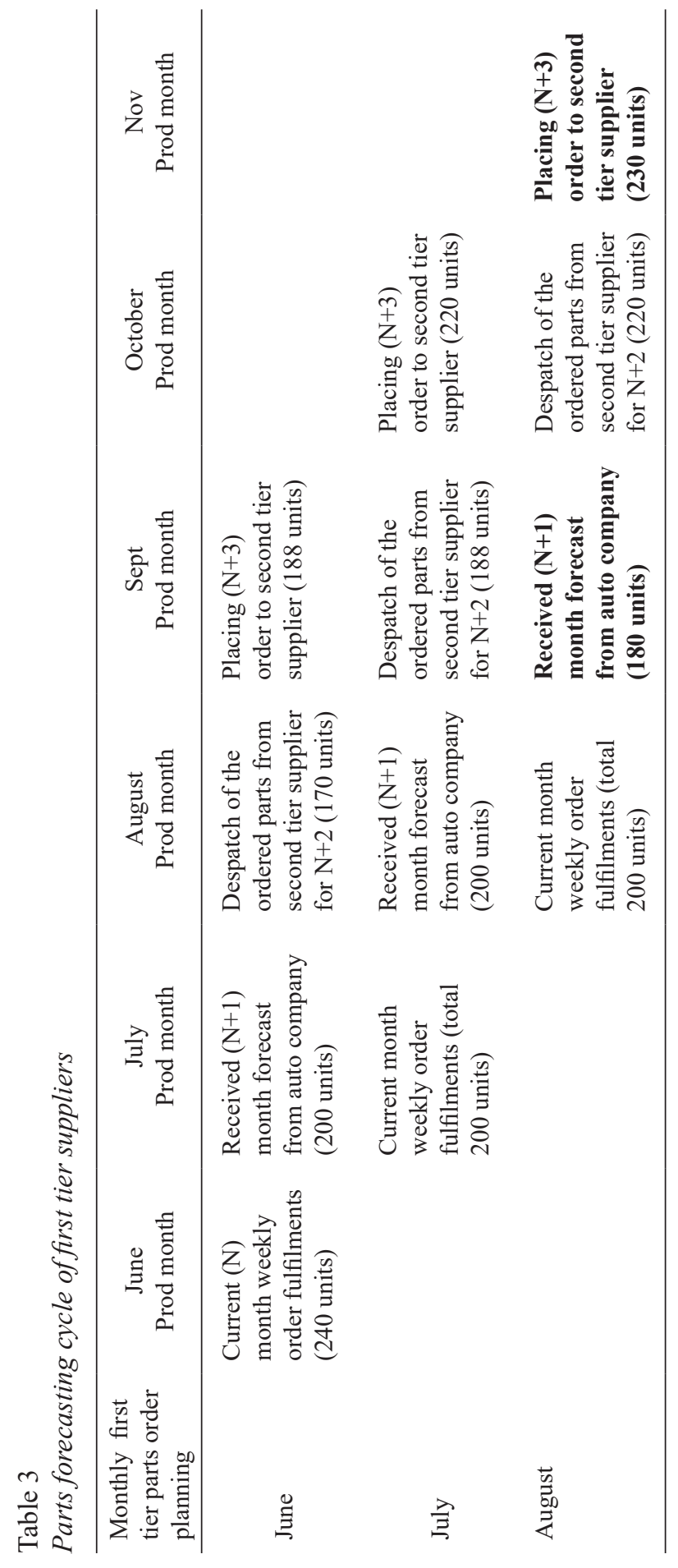




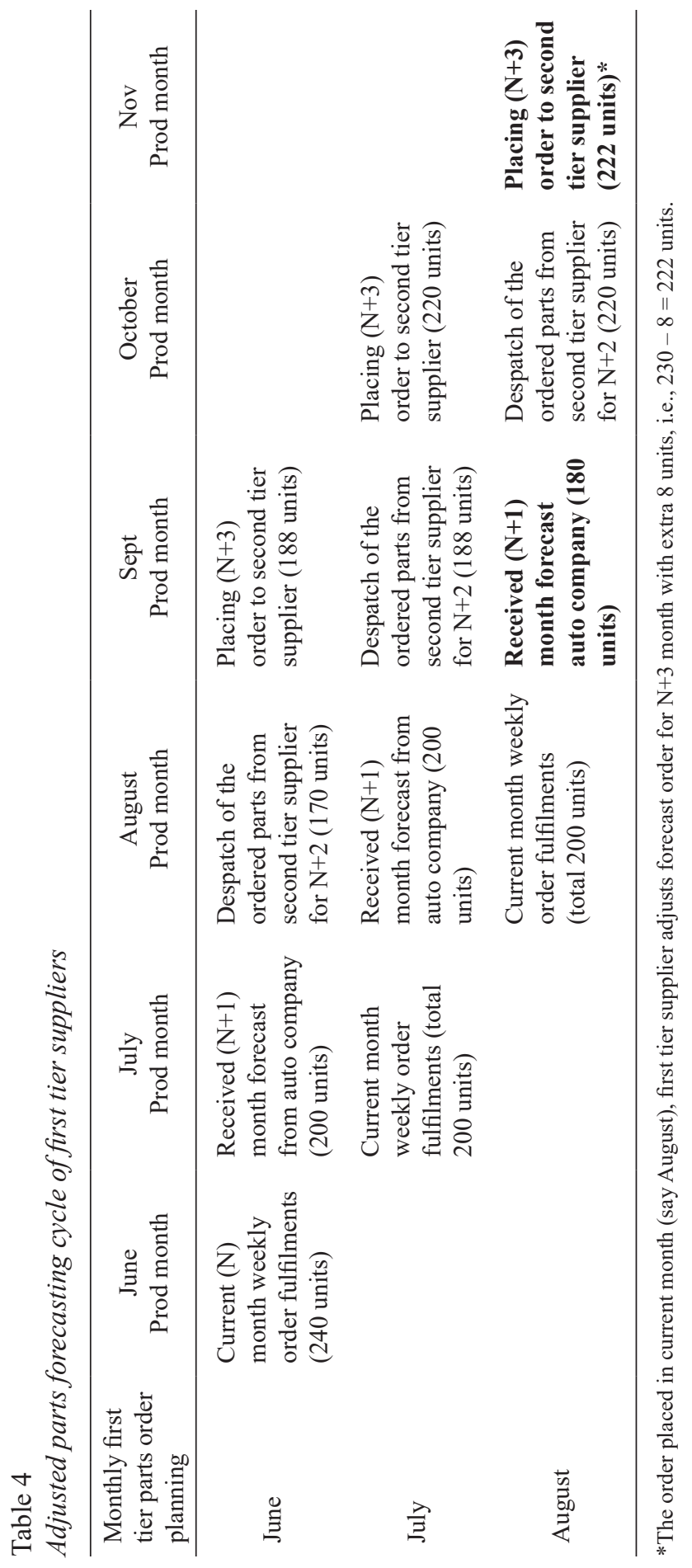


The planned order 'On' is the net quantity of first tier suppliers order to second tier suppliers, given the 10 weeks of lead time available for order fulfilment. The first tier supplier has to make sure of the $\mathrm{SOH}$ availability as per $\mathrm{PO}$ (actual order) requirement at processing sites at least one day before the vessel arrival. This would enable first tier supplier to respond to customer's PO just in time expectations.

The $(\mathrm{N}+3) n$ ordered quantities arrive at first tier parts supplier within first week of $\mathrm{N}+3$ month, or at the same time as actual weekly PO arrival. PO represents the actual quantities that customer (automotive company) orders to first tier two days after vessel departure from Japan (Figure 8). Further, from the experience of business practices, it is possible that parts arrival from second tier suppliers often delayed due to customs or quarantine hold up, weather condition, etc. for a maximum of one week.

In order for Australian automotive part suppliers to achieve the minimal carrying and obsolescence cost, minimise the risk of part shortage, and supporting (customer) company's JIT operations, they need to find out optimum safety stock quantity or buffer at all times. The first tier suppliers need to establish optimum buffer levels taking into consideration the situation at hand (see Figure 8). Under the circumstances, the buffer to be held is an average of two weeks, taken into consideration the risk of one week of possible delay of $\mathrm{N}+3$ order quantities from second tier supplier and one week for fulfilment of actual order from its customer.

Buffer quantity thus can be estimated as the average parts consumption for the last three months (e.g. $\mathrm{N}-1, \mathrm{~N}-2$ and $\mathrm{N}-3$ ) amended with any replacement of possible damaged parts (say, Dp). The buffer helps in meeting the JIT supply in the event of any shipment uncertainty at second tier supplier. The buffer $\left(B f_{n}\right)$ per week (i.e., average of two weeks) is calculated as follow:

$$
\mathrm{Bf}_{\mathrm{n}}=\{[(\mathrm{N}-1)+(\mathrm{N}-2)+(\mathrm{N}-3)] / 3\} / 2+\mathrm{Dp}
$$

Accordingly, the final stock order for $\mathrm{N}+3$ month placed in current $\mathrm{N}$ month (say, FOn) requires amendment of any buffer variation during previous $\mathrm{N}-1$ period. The need for monthly review of established buffer quantity is necessary as sales volumes changes over period. The FOn can be calculated using equations (1) and (2), and $\mathrm{N}-1$ period buffer:

$$
\mathrm{FOn}=\mathrm{On}+\left(\mathrm{Bf}_{\mathrm{n}}-\mathrm{Bf}_{\mathrm{n}-1}\right)
$$

where, $\mathrm{Bf}_{\mathrm{n}-1}$ represents $\mathrm{N}-1$ period buffer. 


\section{DISCUSSION AND IMPLICATIONS}

This exploratory study investigates vehicle parts import process where the lead time issue remains a challenge for the first tier suppliers in Australia. The first tier suppliers coordinate between local auto assemblers and second tier suppliers from overseas where the tight lead time appears to be a matter of concern. The first tier suppliers in Australia are overly dependent on the overseas second tier suppliers for the reason of parts sourcing. The lead time is the time required to receiving, processing, and dispatching the parts to the auto companies. This study looked at the parts import supply chain and import process flow involving overseas suppliers, local first tier suppliers, and auto manufacturers in Australia in order to arrive at a feasible solution for lead time issue. Considering the issues of supplies from distance and lead time pressure in JIT environment, we developed a heuristic model for MTS parts ordering. This will facilitate the first tier supplier to source and store parts early in the process in order to deliver just in time. MTS strategy accompanied by JIT supply approach appears to be the right combination that we are proposing in this context. This proposed MTS strategy is likely to be a new approach in the parts import supply chain. MTS environment will allow the first tier suppliers a short period stock of parts in-house and meeting the orders just in time (Rafiei \& Rabbani, 2012). The simple heuristic for three months rolling forecast will allow the first tier parts suppliers to add or deduct any shortage/excess inventory not withstanding any carrying cost in this process.

Managing a supply chain is all about adaptive to customer requirements (i.e., volume and variety) (Costantino, Dotoli, Falagario, Fanti, \& Mangini, 2012; Fayezi, Zutshi, \& O'Loughlin, 2015), which warrants efficient flow of goods and services from upstream suppliers. The majority of Australian customers have markedly moved away towards a cost effective buying, specifically the small cars, from overseas auto manufacturers. This situation forces the car manufacturers to adapt the changing situation in import chain operations. We explore that the current Australian vehicles importers have been able to successfully achieve vehicle despatch just in time, but they have ignored their first tier suppliers' pain in this process. First tier suppliers have been under consistent stress (karoshi Japanese refers it as 'death from overwork') for parts supply in a given but tight lead time. Angelis et al. (2004) agree that the JIT and lean production experience the greatest job stress, heavier and faster workloads, difficulties in getting time off, and changing job features. Though the focus of this study is not about dealing with JIT stress, we are making our way to simplify the flow that should come at free of stress. As Doran (2001) (citing Voss, 1987) claims 'key philosophy of JIT is simplification', tightening the supply cycle time causes all stress at the level of first tier suppliers. While coordinating the component supply between second tier 
overseas suppliers and auto assemblers in Australia, first tier supplier appears to have stressful delivery they make every time leading to unsustainable situation that affects their service level (Li, Huang, Cheng, Zheng, \& Ji, 2014).

We argue that first tier suppliers will be better off if they are allowed for a forecastbased early sourcing of parts to store and deliver. This proposed heuristics will allow first tier supplier some breathing time to further processing before the parts are moved on to auto assemblers JIT (Bortolotti, Danese, \& Romano, 2013). The adaption of MTS environment will make the chain a hybrid type combining MTS and JIT supply as opposed to the sole JIT supply chain earlier (Rafiei \& Rabbani, 2012). The working principle of MTS/JIT hybrid supply chain can be explained further by using CODP concept. The CODP is a point where customers' desired specifications influence the production value chain (Fayezi et al., 2015). Though much of the ordering pattern is not expected to change from pure JIT type practice to the proposed hybrid MTS/JIT environment, first tier supplier will carry out stock in this instance to meeting the synchronous requirement at auto assembler. The auto assemblers' specification to first tier will not be changed anyway but the pre-stocking will allow first tier to finish the order processing activities around parts supply before delivery. This will most likely ease the stress level of first tier suppliers which is the context under study contributing an improvement of the current practices. With this arrangement, the current JIT delivery schedule between first tier and auto assembler will somehow remain unchanged for current service level. However, the lead time between first tier and second tier will have some effect. Now question is as to what, when, and how many items be ordered if the first tier is proposed to carry the stock in forecast-based MTS environment. The proposed heuristic [FOn $=\mathrm{On}+\left(\mathrm{Bf}_{\mathrm{n}}-\mathrm{Bf}_{\mathrm{n}-1}\right)$ stated in eq. (3)] needs an adjustment on ongoing basis considering the last period excess stocks or any shortages while forecasting the requirements for the next period. This adjustment thus minimises the carrying cost in the process.

The study provides four-fold theoretical contributions as much as it challenges the conventional wisdom in this domain. First, the study contributes to vehicles import supply chain literature by resolving lead time issues using a modified inventory forecast heuristics. Second, this simple-to-use modified heuristic helps estimating the next period stock with a buffer provision that can ease the current tight lead time situation. Third, first tier suppliers will have smooth parts delivery only under hybrid approach combining MTS ordering environment with JIT supply of parts given the second tier is geographically away. Fourth, it strengthens the fact that chain activities further away from the end customers are very likely to resort to MTS practices whereas JIT works well for activities close to end customers without any interruption in service level. This is likely to be true and useful not just 
for an Australian vehicles import supply chain context, but in global context with increased product import in a complex supply chain.

The significant practical contributions are three-fold. First, though the automotive assemblers are deep into JIT philosophy and practices for long time, this study alerts the manufacturers to reassess their engagement with first tier suppliers in order to make a smooth and stress free buyer-supplier dyadic relationship. Second, the study helps understand the first tier suppliers on the importance and scope of potential parts supply in MTS/JIT hybrid operations with no additional carrying cost. Third, while the customer environment gets changed from JIT to MTS type in the same supply chain, the study recommends first tier suppliers a forecast heuristic for MTS optimum quantities purely based on past consumption, buffer, and damages. This is applicable for sourcing of parts from overseas second tier suppliers. It thus offers a simple heuristics encouraging managers to adapt for their ease of practice. This heuristics can be utilised in other industries for achievement of optimum part supply efficiency.

\section{CONCLUSION}

The study began with looking at Australian automotive supply chain that has drawn recently the attention of practitioners and academics as the auto manufacturing plants nearing the closure by the end of 2017. The closure will definitely stop car production at Ford, Holden, and Toyota manufacturing plants encouraging them to step up their current share of vehicles imports. While importing vehicles from overseas market, they need to work closely with the first tier local suppliers who source and supply parts for local fitment. The issue of tight lead time available to first tier suppliers has been neglected in an environment of JIT supply of parts. Addressing this issue first time through this study, we propose a MTS/JIT-based inventory forecasting heuristic for the first tier suppliers to source, stock, and deliver parts JIT to the auto assemblers. The heuristic for rolling three months ordering cycle is thus recommended to help the first tier suppliers to source and stock without much issue of bullwhip effect of carrying extra parts inventory (Lee, Padmanabhan, \& Whang, 2004; Lin, Jiang, Liu, \& Wang, 2014). The proposed heuristics will likely to ease the lead time issue with no loss of current service level.

The study has some limitations. The current methodology is limited to exploratory data retrieval from industry reports and published statistics revealing very limited information. Though the current parts forecast heuristic appears to have a sound theoretical base, the future research will undertake few case studies of Australian 
automotive companies and first tier suppliers to identify any other possible issues that might hinder this proposed dual-mode operations. Unless few cases are investigated, it is likely that our recommended heuristics may become detached from the real life practice. Also we propose a prototype of this recommendation be undertaken at Townsville (NQ) and Brisbane (SQ) site to see if the heuristics will work. Further an overarching review of stakeholder relationship among manufacturer, first tier suppliers and overseas second tier suppliers in future study will help further sorting out the lead time issues.

\section{REFERENCES}

Angelis, J., Conti, R., Cooper, C., Faragher, B., \& Gill, C. (2004). The effects of just-intime/lean production practices on worker job stress. Paper presented at the Second World Conference on POM and 15th Annual POM Conference, Cancun, Mexico.

Bartezzaghi, E., Cagliano, R., Caniato, F., \& Ronchi, S. (Eds.). (2016). A journey through manufacturing and supply chain strategy research. Switzerland: Springer International Publishing.

Bennett, D., \& Klug, F. (2012). Logistics supplier integration in the automotive industry. International Journal of Operations \& Production Management, 32(11), 12811305. https://doi.org/10.1108/01443571211274558

Bortolotti, T., Danese, P., \& Romano, P. (2013). Assessing the impact of just-in-time on operational performance at varying degrees of repetitiveness. International Journal of Production Research, 51(4), 1117-1130. https://doi.org/10.1080/002 07543.2012.678403

Costantino, N., Dotoli, M., Falagario, M., Fanti, M.P., \& Mangini, A.M. (2012). A model for supply management of agile manufacturing supply chains. International Journal of Production Economics, 135, 451-457. https://doi.org/10.1016/j. ijpe.2011.08.021

Daugherty, P.J., Rogers, D.S., \& Spencer, M.S. (1994). Just-in-time functional model: Empirical test and validation. International Journal of Physical Distribution \& LogisticsManagement, 24(6),20-26.https://doi.org/10.1108/09600039410066150

Doran, D. (2001). Synchronous supply: An automotive case study. European Business Review, 13(2), 114-120. https://doi.org/10.1108/09555340110385290

Fahimnia, B., Farahani, R.Z., \& Sarkis, J. (2013). Integrated aggregate supply chain planning using memetic algorithm: A performance analysis case study. International Journal of Production Research, 51(18), 5354-5373. https://doi.org/10.1080/00 207543.2013.774492

Fayezi, S., Zutshi, A., \& O'Loughlin, A. (2015). How Australian manufacturing firms perceive and understand the concepts of agility and flexibility in the supply chain. International Journal of Operations \& Production Management, 35(2), 246-281. https://doi.org/10.1108/IJOPM-12-2012-0546 
FCAI (Federal Chamber of Automotive Industries). (2015). VFACTS National Report: New Vehicle Sales, Federal Chamber of Automotive Industries (FCAI). Retrieved 15 February 2016 from https://www.fcai.com.au/news/publication/index/year/all/ month/all/publication/84

Fiksel, J., Polyviou, M., Croxton, K., \& Pettit, T. (2015). From risk to resilience: Learning to deal with disruption. MIT Sloan Management Review, 56(2), 79-86. https://doi.org/10.5822/978-1-61091-588-5_2

Gunasekaran, A., Subramanian, N., \& Rahman, S. (2015). Supply chain resilience: Role of complexities and strategies. International Journal of Production Research, 53(22), 6809-6819. https://doi.org/10.1080/00207543.2015.1093667

Harber, D., Samson, D., Sohal, A., \& Wirth, A. (1990). Just-in-time: The issue of implementation. International Journal of Operations \& Production Management, 10(1), 21-30. https://doi.org/10.1108/01443579010001681

Hoekstra, S., \& Romme, J. (1992). Integrated logistics structures: Developing customer oriented goods flow. London: McGraw-Hill.

Jacobs, F.R., Berry, W., Whybark, D.C., \& Vollmann, T. (2011). Manufacturing planning \& control for supply chain management (6th ed.). New York: Irwin McGraw-Hill.

Jayamaha, N.P., Wagner, J.P., Grigg, N.P., Campbell-Allen, N.M., \& Harvie, W. (2014). Testing a theoretical model underlying the 'Toyota Way': An empirical study involving a large global sample of Toyota facilities. International Journal of Production Research, 54(4), 4332-4350. https://doi.org/10.1080/00207543.201 4.883467

Jayaram, J., Das, A., \& Nicolae, M. (2010). Looking beyond the obvious: Unraveling the Toyota production system. International Journal of Production Economics, 128(1), 280-291. https://doi.org/10.1016/j.ijpe.2010.07.024

Jodibauer, H., Olhager, J., \& Schonberger, R.J. (2012). The role of decoupling points in value chain management. In H. Jodlbauer, J. Olhager, \& R.J. Schonberger (Eds.), Modelling value. Selected papers of the 1st International Conference on Value Chain (pp. 37-47). Berlin: Springer.

Lee, H.L., Padmanabhan, V., \& Whang, S. (2004). Information distortion in a supply chain: The bullwhip effect. Management Science, 50(12 supplement), 1875-1886. https://doi.org/10.1287/mnsc.1040.0266

Li, G., Huang, F.F., Cheng, T.C.E., Zheng, Q., \& Ji, P. (2014). Production, manufacturing and logistics: Make-or-buy service capacity decision in a supply chain providing after-sales service. European Journal of Operational Research, 239(2), 377-388. https://doi.org/10.1016/j.ejor.2014.05.035

Li, L. (2013). The path to Made-in-China: How this was done and future prospects. International Journal of Production Economics, 146(1), 4-13. https://doi.org/ 10.1016/j.ijpe.2012.11.005 \& https://doi.org/10.1016/j.ijpe.2013.05.022

Lii, P., \& Kuo, F.-I. (2016). Innovation-oriented supply chain integration for combined competitiveness and firm performance. International Journal of Production Economics, 174, 142-155. https://doi.org/10.1016/j.ijpe.2016.01.018

Liker, J. (2003). The Toyota way: Fourteen management principles from the world's greatest manufacturer. New York: McGraw-Hill. 
Liker, J., \& Wu, Y. (2000). Japanese automakers, US suppliers and supply-chain superiority. Sloan Management Review, 42(1), 81-93.

Lin, W.-J., Jiang, Z.-B., Liu, R., \& Wang, L. (2014). The bullwhip effect in hybrid supply chain. International Journal of Production Research, 52(7), 2062-2084. https://doi.org/10.1080/00207543.2013.849013

McCutcheon, D.M., \& Meredith, J.R. (1993). Conducting case study research in operations management. Journal of Operations Management, 11(3), 239-256. https://doi.org/10.1016/0272-6963(93)90002-7

Morris, D., Donnelly, T., \& Donnelly, T. (2004). Supplier parks in the automotive industry. Supply Chain Management: An International Journal, 9(2), 129-133. https://doi. org/10.1108/13598540410527024

Ōno, T. (1988). Toyota production system: Beyond large-scale production. London: Productivity Press.

Prajogo, D., Oke, A., \& Olhager, J. (2016). Supply chain processes: Linking supply logistics integration, supply performance, lean processes and competitive performance. International Journal of Operations \& Production Management, 36(2), 220-238. https://doi.org/10.1108/IJOPM-03-2014-0129

Productivity Commission. (2014). Australia's automotive manufacturing industry. Retrieved 10 October 2016 from http://www.pc.gov.au/inquiries/completed/ automotive

Productivity Commission. (2016). Trade and assistance review 2014-15. Retrieved 10 October 2016 from http://www.pc.gov.au/research/ongoing/tradeassistance/2014-15

Rafiei, H., \& Rabbani, M. (2012). Capacity coordination in hybrid make-to-stock/maketo-order production environments. International Journal of Production Research, 50(3), 773-789. https://doi.org/10.1080/00207543.2010.543174

Robson, C., \& McCartan, K. (2016). Real world research (4th ed.). London: John Wiley $\&$ Sons.

Russell, S.H. (2000). Growing world of logistics. Air Force Journal of Logistics, 24(4), 13-17.

Shipping Schedules. (2015). Interactive schedule. Retrieved 20 March 2015 from http://web.molpower.com/NaviGator/Schedule.

Singh, P.J., Smith, A., \& Sohal, A.S. (2005). Strategic supply chain management issues in the automotiveindustry:AnAustralian perspective.InternationalJournalofProduction Research, 43(16), 3375-3399. https://doi.org/10.1080/00207540500095738

Soman, C.A., Van Donk, D.P., \& Gaalman, G. (2004). Combined make-to-order and make-to-stock in a food production system. International Journal of Production Economics, 90(2), 223-235. https://doi.org/10.1016/S0925-5273(02)00376-6

Svensson, G. (2003). The principle of balance between companies' inventories and disturbances in logistics flows: Empirical illustration and conceptualisation. International Journal of Physical Distribution \& Logistics Management, 33(9), 765-784. https://doi.org/10.1108/09600030310503325

Tcha, M., \& Kuriyama, T. (2003). Protection policy under economies of scale: The welfare effects of tariffs on the Australian automotive industry. Journal of Policy Modeling, 25(6/7), 655-672. https://doi.org/10.1016/S0161-8938(03)00059-0 
The Australian. (2014, 15 February). Toyota to stop making cars in Australia, follows Ford and Holden. Retreived 10 February 2016 from http://www.theaustralian.com.au/ business/news/toyota-to-stop-making-cars-in-australia-follows-ford-and-holden/ news-story/c446dddef6098aed1361d200040bc1c6.

TMCA (Toyota Motor Corporation of Australia). (2004). TPS principles: Participant's self-guided workbook. Melbourne: TMCA.

TNT. (2015). Average lead time data. Retrieved August 2015 from http://www.tnt.com/ express/en au/site/home/applications/tracking.html.

Toyota. (2016). Order tracking system. Retrieved 14 January 2016 from https://webapps. toyota.com.au/apps/cwt/.

Womack, J.P., \& Jones, D.T. (1996). Beyond Toyota: How to root out waste and pursue perfection. Harvard Business Review, 74(5), 140-158.

Wright, C.F. (2006). The social dimension of the integration of Australian automotive manufacturing into global supply chains. Employment Relations Record, 6(2), 47-59.

Wu, K.-J., Tseng, M.-L., Chiu, A.S., \& Lim, M.K. (2016, in press, corrected proof). Achieving competitive advantage through supply chain agility under uncertainty: A novel multi-criteria decision-making structure. International Journal of Production Economics. https://doi.org/10.1016/j.ijpe.2016.08.027 